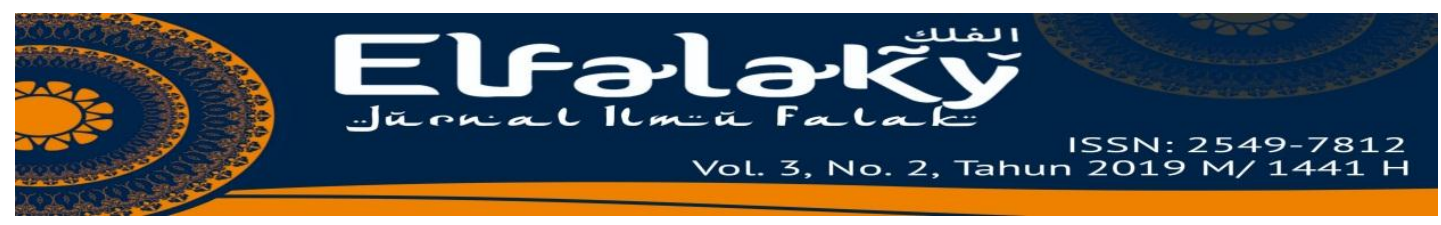

\title{
Menelaah Perkembangan Kajian Hisab Rukyah di Indonesia
}

\author{
Heri Zulhadi
}

Heryhyzad@gmail.com

\begin{abstract}
Hisab and rukyah are two methods of study used by Muslims to determine the start time of prayer, fasting, hajj and so forth. Periodesasi hisab rukyah, at a glance must have imagined what is meant by hisab rukyah. In the discourse about the Hijri calendar known by the term hisab and rukyah. Hisab is a calendar calculation system based on the average circulation of the moon that surrounds the earth and is conventionally defined. This reckoning system began since the establishment of Caliph Umar ibn Khattab ra (17H) as a reference for composing an enduring Islamic calendar. Another opinion says that this calendar system started in $16 \mathrm{H}$ or $18 \mathrm{H}$, but the more popular is the year $17 \mathrm{H}$. While Rukyah is seeing the hilal directly with the naked eye or with the help of tools such as telescopes or other tools that support to see the new moon every end of Qamariyah month. The word rukyah is more famous as rukyatul hilalyaitu see moon. In this study, the author will describe a little about the history of hisab and rukyah in the period of prophets, companions, tabi'in, mid to modern period today. In this study, the scope of hisab rukya includes prayer times, Qibla direction, the beginning of Qamariyah month, eclipse and hijri calendar.
\end{abstract}

\section{Keyword: Hisab, Rukyah.}

\section{Pendahuluan}

Dari sekian banyak cabang ilmu, ilmu falak menempati posisi strategis dalam Islam, karena hal itu terkait dengan beberapa aspek ibadah yang secara langsung bersentuhan dengan kegiatan ibadah sehari-hari seperti halnya ibadah shalat yang mencakup seluruh umat muslim dalam sebuah negara bahkan boleh jadi dalam lingkup dunia Islam.

Dalam tulisan ini, ada beberpa hal penting dalam ibadah yang terkait langsung dengan hisab dan rukyah: menentukan awal bulan Qamariyah, jadwal shalat, arah kiblat, menentukan kapan dan di mana akan terjadi gerhana, dan penanggalan hijriyah. Sampai saat ini, belum ada satu sistem yang disepakati dan digunakan bersama-sama karena penentuan tersebut merupakan masalah Ijtihād.Dalam tulisan ini, akan diulas bagaimana sejarah hisab rukyah dimulai dari masa nabi, masa sahabat, masa tabi'in, masa pertengahan, sampai masa modern saat ini.

Dalam perkembangan ilmu falak, penentuan awal ramadhan dan hari raya tidak lagi dapat dikatakan mudah. Dari segi teknis ilmiah sebenarnya penentuan memang mudah dikarenakan memang merupakan bagian dari ilmu eksakta. Akan tetapi dalam penerapannya di masyarakat sangat sulit untuk dilakukan karena menyangkut masalah syar'i (fiqh) atau menyangkut banyak umat.

\section{A. Pengertian Hisab dan Rukyah}

\section{Pengertian Hisab}

Hisab berasal dari bahasa Arab hisban, hisaaban atau hisaabatan yang bermakna menghitung. Kata ini cukup populer dalam bahasa Arab dan memiliki beragam bentuk dan makna. Jika diartikan menghitung, kata ini berakar dari fi'il 
madihasaba yahsubu. Berbeda jika dari bentuk hasiba yahsabu, bentukan kata ini diartikan sebagai menduga, menyangka atau mengira.

Secara etimologi hisab berasal dari kata hasiba-yahsabuhusbanan/hisaban yang artinya perhitungan dan dalam bahasa Inggris berbentuk arithmatic. Secara istilah ilmu hisab adalah ilmu pengetahuan yang membahas tentang seluk beluk perhitungan atau lebih sederhana adalah ilmu hitung. ${ }^{1}$

Lebih jelasnya, hisab berarti hitungan, perhitungan, arithmetic (ilmu hitung), calculus (hitung), computation (perhitungan), calculation (perhitungan), estimation (penilaian, perhitungan), appraisal (penaksiran). ${ }^{2}$ Semua makna tersebut terkait dengan kegiatan mnghitung seperti tersurat dalam al-Qur'an surat Yunus ayat 5, Al-Isra' ayat 12 dan Ar-Rahman ayat 5. Oleh sebab itu, ilmu hisab bermakna ilmu hitung atau arithmetic, yaitu suatu ilmu pengetahuan yang membahas tentang seluk beluk pehitungan.

Selanjutnya dengan berfokus pada makna diatas, hisab sering disinonimkan dengan kata falak, miqat, rasdu, haiah hingga astronomi. Adapun secara istilah, kata hisab sendiri memiliki beragam definisi pula, diantaranya menurut Muhyidin Khazin yang memaknai hisab atau falak sebagai ilmu pengetahuan yang mempelajari lintasan benda-benda langit khususnya Bumi, Bulan, dan Matahari pada orbitnya masing-masing dengan tujuan untuk diketahui posisi benda langit antara satu dengan lainnya, agar dapat diketahui waktu-waktu di permukaan bumi. ${ }^{3}$

Sedangkan menurut Ahmad Izzuddin, ilmu hisab didefinisikan sebagai ilmu yang mempelajari tentang lintasan benda-benda langit, diantaranya Bumi, Bulan, dan Matahari. Benda-benda Langit tersebut berjalan sesuai orbitnya masingmasing. Dan dengan orbit tersebut dapat digunakan untuk mengetahui posisi benda langit antara satu dengan lainnya. Sedang makna ini disinonimkan dengan hisab adalah karena kegiatan yang paling menonjol dari ilmu adalah dengan melakukan perhitungan-perhitungan. Namun meski demikian, Ahmad Izzuddin tidak sepenuhnya sepakat dengan penggunaan istilah ilmu hisab, karena dalam keilmuan ini cara kerja ilmiahnya tidak semata-mata dengan hisab (perhitungan), namun juga dengan rukyah (observasi). Hingga menurut beliau lebih tepat jika dikatakan ilmu hisab rukyat. ${ }^{4}$

Sementara itu, istilah hisab adalah perhitungan benda-benda langit untuk mengetahui kedudukannya pada suatu saat yang diinginkan. Apabila hisab ini dalam penggunaannya dikhususkan pada hisab waktu atau hisab awal bulan maka yang dimaksudkan adalah menentukan kedudukan matahari atau bulan sehingga diketahui kedudukan matahari dan bulan tersebut pada bola langit pada saat-saat tertentu. ${ }^{5}$

Adapun pokok bahasan dalam ilmu ini adalah menentukan waktu dan posisi benda langit yang secara langsung ataupun tidak memiliki implikasi terhadap pelaksanaan ibadah yang terikat dengan waktu. Hingga obyek kajian ilmu ini adalah berkisar pada penentuan arah kiblat, awal waktu shalat, awal bulan (yakni bulanbulan hijriyah khususnya ramadhan, syawwal dan dzulhijjah) serta penentuan gerhana matahari dan bulan. ${ }^{6}$

\footnotetext{
${ }^{1}$ Direktorat Jenderal Bimas Islam, Almanak Hisab Rukyat, (Jakarta : KEMENAG, 2010), h. 20.

${ }^{2}$ Maskufa, Ilmu Falaq. Jakarta: Gaung Persada. 2009, h. 147.

${ }^{3}$ Muhyiddin Khazin, Ilmu Falak dalam Teori dan Praktik. Yogyakarta: Buana Pustaka. 2011, h.1.

${ }^{4}$ Ahmad Izzuddin,Ilmu Falak Praktis. Semarang: Pustaka Rizki Putra. 2012, h. 4.

${ }^{5}$ Maskufa, Ilmu Falaq., h. 148.

${ }^{6}$ Ahmad Izzuddin, Ilmu Falak Praktis dan dalam bukunya Fiqh Hisab Rukyah. Jakarta : Erlangga.
} 2007. h. 41. 
Sedangkan perangkat keilmuan, pendekatan, tata cara dan metode yang digunakan tentu saja tidak stagnan dan selalu berkembang dari masa ke masa sesuai perkembangan keilmuan dan teknologi manusia. Maka wajar jika hisab yang kita pahami dan praktekkan pada saat ini berbeda dengan karya ulama' terdahulu dalam kitab klasik, terlebih dengan masa awal kelahiran Islam di kurun abad ke-7 hingga 8 Masehi.

Jadi bisa disimpulkan bahwa yang dimaksud ilmu hisab dalam pembahasan ini adalah ilmu hisab sebagai ilmu falak yang digunakan umat Islam dalam menjalani kegiatan ibadah. Ia hanya memberikan hasil perhitungan terkait persoalan waktu dan posisi saja, dan tidak dapat mengatakan secara rinci bahwa hilal (bulan) pada posisi tertentu pasti atau mustahil dapat terlihat. ${ }^{7}$

\section{Pengertian Rukyah}

Rukyat menurut bahasa berasal dari kata ra'a, yara, ra'yan, wa ru'yatan yang bermakna melihat, mengerti, menyangka, menduga dan mengira, ${ }^{8}$ to see, to behold (melihat), perceive (merasa), notice, observe, (memperhatikan/melihat) dan discern (melihat). Dalam khazanah fiqh, kata rukyah lazim disertai dengan kata hilal sehingga menjadi rukyatul hilal yang berarti melihat hilal (bulan baru). Rukyatul hilal ini berkaitan erat dengan masalah ibadah terutama ibadah puasa. Hal ini sesuai dengan hadits nabi yang diriwayatkan oleh Imam Muslim:

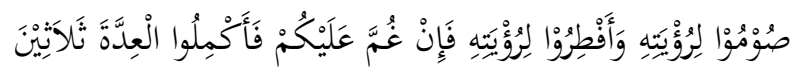

Artinya"Apabila kamu melihat hilal, maka berpuasalah dan bila kamu melihat hilal maka berbukalah, jika berawan (tidak bisa melihatnya) maka sempurnakanlah hitungan bulan Sya'ban menjaga tiga puluh (30).".'

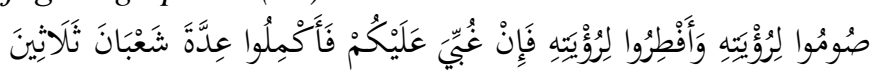

Artinya : Berpuasalah kalian karena melihatnya (hilal) dan berhari rayalah karena melihatnya, jika hilal hilang dari penglihatanmu maka sempurnakan bilangan

Sya'ban sampai tiga puluh hari. (HR. Bukhari No. 1909).

Rukyah menurut istilah adalah melihat hilal pada saat matahari terbenam tannggal 29 bulan Qamariyyah. Kalau hilal berhasil dirukyah maka sejak matahari terbenam tersebut sudah dihitung bulan baru, kalau tidak terlihat maka malam itu dan keesokan harinya masih merupakan bulan yang berjalan dengan digenapkan (istikmal) menjadi 30 hari. $^{10}$

Rukyah dimaksudkan untuk menentukan awal bulan Ramadhan, Syawal, dan Dzulhijjah. Dua bulan yang pertama berkaitan dengan ibadah puasa dan ketiga bekaitan dengan ibadah haji. Keberhasilan rukyatul hilal sangat bergantung pada kondisi ufuk disebelah barat tempat peninjau, posisi hilal dan kejelian mata.

Rukyah disini adalah aktivitas mengamati visibilitas hilal, yakni penampakan bulan sabit yang pertama kali tampak setelah terjadinya ijtimak. Rukyat dapat dilakukan dengan mata telanjang, atau dengan alat bantu optik seperti teleskop.

Namun, tidak selamanya hilal dapat terlihat. Jika selang waktu antara ijtimak dengan terbenamnya matahari terlalu pendek, maka secara ilmiah/teori hilal mustahil terlihat, karena iluminasi cahaya Bulan masih terlalu suram dibandingkan dengan "cahaya langit" sekitarnya. Kriteria bahwa hilal dapat terlihat tanpa alat bantu jika minimal jarak sudut (arc of light) antara bulan-matahari sebesar 7 derajat.

\footnotetext{
${ }^{7}$ Ibid.h. 2.

${ }^{8}$ Ahmad Warson Munawwir, Al-Munawwir Kamus Arab Indonesia. Yogyakarta: PP AlMunawwir Krapyak, 1984. h.495.

${ }^{9}$ Maskufa, Ilmu Falaq., h. 149.

${ }^{10}$ Maskufa, Ilmu Falaq., h. 149.
} 


\section{B. Ruang Lingkup Hisab dan Rukyah}

Kajian hisab dan rukyah yang menjadi pembahasan dalam tulisan ini sebagaimana dibeberapa literatur setidaknya ada 5 hal yang dikaji, yaitu:

1. Waktu shalat

2. Arah kiblat

3. Awal bulan kamariyah

4. Terjadinya gerhana, dan

5. Penanggalan (kalender).

\section{Hisab Rukyah dalam Lintasan Sejarah}

Secara historis, rukyah lebih dulu ada dan berkembang dibandingkan dengan hisab. Rukyah adalah satu-satunya cara dalam menentukan awal bulan Qamariyyah sejak masa sebelum Islam. ${ }^{11}$

Merujuk pada penemu pertama ilmu hisab atau astronomi (nabi Idris), ${ }^{12}$ sebagaimana disebutkan dalam setiap mukadimah kitab-kitab falak tampak bahwa wacana (persoalan) hisab rukyah sudah ada sejak zaman itu atau bahkan lebih awal. Karena suatu temuan baru biasanya merupakan suatu respon atau tanggapan dari suatu persoalan yang muncul dalam suatu masyarakat. Sehingga kemunculan hisab rukyah dalam telusuran sejarah dapat diyakini muncul sebelum temuan ilmu falak itu sendiri. ${ }^{13}$

Sedangkan pengetahuan tentang nama-nama hari dalam seminggu sudah ada sejak 5.000 tahun sebelum masehi yang masing-masing diberi nama dengan nama-nama benda langit, Matahari untuk hari ahad, Bulan untuk hari senin, Mars untuk hari selasa, Merkurius untuk hari rabu, Jupiter untuk hari kamis, Venus untuk hari jum'at, dan Saturnus untuk hari sabtu. ${ }^{14}$ Kemudian pada abad 20 SM juga telah ditemukan alat untuk mengetahui gerak matahari dan benda-benda langit lainnya di negri Tionghoa ${ }^{15}$ dan berlanjut pada asumsi Phytagoras 580-500 SM (bumi berbentuk bola bulat), Heraklitus dari Pontus 388-315 SM (bumi berputar pada sumbunya, Mercurius dan Venus mengelilingi matahari dan matahari mengelilingi bumi) ${ }^{16}$ kemudian Aristarchus dari Samos 310-230 SM (Pengukuran jarak bumi dan matahari, dan menyatakan bumi beredar mengelilingi matahari), dan Eratosthenes dari Mesir 276-196 SM (sudah dapat menghitung keliling bumi). ${ }^{17}$ Dari situ dapat disimpulkan bahwa sejak sebelum masehi ternyata sudah tampak adanya persoalan hisab rukyah walaupun dalam kemasan yang berbeda. ${ }^{18}$

Kemajuan peradaban suatu bangsa atau wilayah pada dasarnya memang sangat dipengaruhi oleh kemajuan pengetahuan yang dicapai di zamannya. Begitu pula dalam ranah kajian ilmu hisab atau falak yang pernah menjadi bagian dari golden age kebudayaan dan peradaban Islam. Namun tidak bisa dipungkiri kalau perkembangan keilmuan selalu bersifat melengkapi dan bahkan menjadi antithesis dari penemuan dari manusia di zaman atau peradaban sebelumnya.

Tak terkecuali dalam keilmuan ini, Dr. Yahya Syami sebagaimana dikutip oleh Susiknan Azhari membagi perkembangan ilmu falak dalam dua fase, yakni fase Pra Islam dan fase Islam. Fase pra-Islam dimulai dari bangsa Babilonia

$16-17$.

${ }^{11}$ Maskufa, Ilmu Falaq., h. 155.

${ }^{12}$ Zubaer Umar Jaelany, op. Cit., h.5.

${ }^{13}$ Ahmad Izzuddin, Fiqh Hisab Rukyah, h. 47-48.

${ }^{14}$ Thanthawy al-Jauhary, Tafsir al-Jawahir, juz VI, Mesir: Musthafa al-Babi al-Habibi, 1346 H, h.

\footnotetext{
${ }^{15}$ Abdul Latif Abu Wafa, Al-Falak al-Hadis, Mesir: al-Qatr, 1933 M, h.3.

${ }^{16}$ Rudolf, There Was Light, New York: Alfred A Knopt, 1957, h. 85.

${ }^{17}$ Marsito, Kosmografi Ilmu Bintang-bintang, Jakarta: Pembangunan, 1960, h. 8.

${ }^{18}$ Ahmad Izzuddin, Fiqh Hisab Rukyah, h. 49.
} 
yang banyak menggunakan petunjuk gerakan benda langit sebagai pedoman atau ramalan kehidupan mereka. Meski demikian, bangsa ini sudah mampu mengetahui kapan terjadinya gerhana dengan petunjuk rasi bintang. Dalam bentuk sederhana, mereka pun sudah menciptakan tabel-tabel kalender khusus untuk pergantian musim, waktu, bulan, gerhana dan pemetaan langit. Masyarakat Babilonia juga yang merumuskan penetapan waktu dalam satu hari sebanyak 24 jam. Dimana satu jam adalah 60 Menit dan satu menit adalah 60 detik, mereka menyebutnya dengan sebutan hukum Sittiny yaitu hukum per-enam puluh. Karena mereka menganggap bahwa keadaan bumi adalah bulat dan berbentuk lingkaran 360 derajat dan pembagiannya habis dengan 60 . Selain itu, mereka juga telah menetapkan peredaran bulan mengelilingi bumi membutuhkan waktu 29. 530594 hari. $^{19}$

Setelah Babilonia, terdapat bangsa Mesir Kuno yang mampu menangkap fenomena alam berupa pasang surutnya sungai Nil yang ditandai dengan munculnya bintang Sirius di sebelah selatan setiap tanggal 19 tamuz atau juli. Selain itu terdapat pula bangsa Mesopotamia, Cina, India, Perancis serta Yunani yang memunculkan teori dan warna baru dalam perkembangan astronomi manusia.

Dari fase ini, agaknya Yunani yang banyak berpengaruh dalam perkembangan astronomi dan keilmuan falak (hisab) Arab. Saat Masa kejayaan Yunani berakhir, pusat peradaban dan perkembangan ilmu dunia memang berpusat pada dunia Timur yang notabene di bawah kekuasaan Islam. Masa ini tergolong cukup lama dibanding peradaban lain yakni selama kurang lebih 14 abad. Fakta sejarah menyatakan, masa Golden age dunia Islam memang berbanding terbalik dengan dunia Barat yang berada dalam masa kegelapan (dalam keilmuan Filsafat biasa dikatakan sebagai fase skolastik) dan berada di bawah kontrol gereja. Berfokus pada perkembangan falak di dunia Islam, Donald Routledge sebagaimana dikutip Anton Ramdan membaginya dalam 4 periode secara spesifik, yakni ${ }^{20}$ :

1) Periode $700 \mathrm{M}-825 \mathrm{M}$

Yakni masa penerjemahan buku-buku astronomi dari India dan Yunani seperti Zij al-Sindhind, Almagest karya Ptolemy dan penulisan buku astronomi Zij ala Sinin al-Arab oleh Muhammad al-Fazari pada $790 \mathrm{M}$.

2) Periode $825 \mathrm{M}-1025 \mathrm{M}$

Yakni di masa pemerintahan Abbasiyyah dengan adanya Baitul Hikmah yang menjadi wadah lahir dan berkembangnya pengetahuan dan peradaban Islam. Dari masa ini muncullah nama al-Khawarizmi, al-Farghani, Muhammad Ibnu Musa hingga matematikawan dan astronom Abu Wafa Muhammad ibnu Muhammad al-Buzjani.

3) Periode $1025 \mathrm{M}-1450 \mathrm{M}$

Di masa ini Islam memiliki Ibnu al-Haitham yang mempelopori ilmu astronomi ${ }^{21}$ berdasar penelitian dengan teleskop, al-Biruni dengan magnum opusnya kitab al-Qanun al-Mas'udi, Ulugh Beg dan sebagainya.

4) Periode $1450 \mathrm{M}-1900 \mathrm{M}$

Masa ini adalah masa kemunduran keilmuan falak dan astronomi Islam yang ironisnya bersamaan dengan menggeliatnya dunia keilmuan di Barat pasca masa Renaisense. Di masa ini tidak banyak penemuan

\footnotetext{
${ }^{19}$ http://erwandigunawandly.blogspot.co.id/2014/06/historisitas-hisab-i-kaleidoskop.html. Diakses pada tanggal 15 November 2017.

${ }^{20} \mathrm{http} / / /$ erwandigunawandly.blogspot.co.id/2014/06/historisitas-hisab-i-kaleidoskop.html. Diakses pada tanggal 15 November 2017.

${ }^{21}$ Muhammad Al-Farabi Putra, Pemikiran Ibn Al-Khaitam. Makalah Mata Kuliah Pemikiran "Hisab Rukyah Klasik" UIN Walisongo Semarang, disampaikan pada tanggal 20 0ktober 2017. h. 17.
} 
astronomi yang berarti dan penting selain pendirian observatorium astronomi di Istambul oleh Taqi al-Din bin Ma'ruf.

Menariknya, dari pembagian fase periode ini, tidak banyak ditemukan literatur dan referensi yang menjelaskan detail terkait perkembangan keilmuan ini di kurun abad awal hijriah. Padahal fase ini adalah masa kehidupan nabi Muhammad dan sahabat atau tabi'in yang otomatis adalah masa ayat-ayat al-Quran dan hadis masih berproses turun dan berdialektika. Artinya, saat itu umat Islam mengalami fase perpindahan yang cukup signifikan, dari keyakinan nenek moyang menuju agama samawi terakhir, dari aktifitas sosial dan keagamaan warisan turun temurun menuju pola interaksi yang digariskan dalam al-Quran, khususnya taklif terkait ibadah tertentu yang sangat terikat dengan waktu dan otomatis terkait dengan keilmuan falak dan hisab. ${ }^{22}$

\section{a. Hisab Rukyah pada Masa Nabi Muhammad saw}

Nabi Muhammad saw. diutus pada masyarakat Makkah pada saat itu sudah berkembang menjadi sentral perdagangan dan transaksi keuangan yang cukup ramai dengan pola kesukuan dan stratifikasi sosial yang demikian kental. Hal tersebut membuat jalan dakwah nabi menjadi sulit, yang puncaknya adalah pemboikotan terhadap nabi dan pengikutnya yang mengakibatkan wafatnya orang-orang yang sangat dicintai dan diseganiya. Maka tantangan dakwah semakin hebat menimpa nabi dan pengikutnya, pada akhirnya menghantarkan nabi untuk berhijrah ke Madinah. ${ }^{23}$

Kehadiran nabi di Madinah diterima dengan tangan terbuka oleh saudaranya sesama muslim, tetapi tidak demikian dengan mereka yang belum memeluk Islam. Mereka merasa terusik dengan kehadirannya itu. Untuk terciptanya kebersamaan, saling menghormati dan rasa memiliki Madinah maka nabi menggagas dibuatnya perjanjian yang dikenal dengan "Piagam Madinah".Madinah pada waktu itu dikenal sebagai daerah transit perdagangan dari Syam dan sekitarnya menuju Makkah. Maka, penanggalan sudah dikenal oleh penduduk Madinah jauh sebelum nabi datang. Ada dua sistem penanggalan yang mereka kenal yaitu penanggalan Yahudi dan sistem penanggalan Syamsiyah yang menekankan pada keajegan perubahan musim tanpa memperhatikan perubahan harinya dan penanggalan warisan nenek moyang dengan sistem penanggalan Qomariyah. ${ }^{24}$

Penanggalan sistem Qamariyah digunakan oleh penduduk Madinah yang mayoritas bermata pencaharian bercocok tanam untuk menentukan awal bulan dengan mudah yakni dengan melihat fase-fase perubahan bulan itu sendiri dalam tiap bulannya. Akan tetapi, dengan penanggalan ini mereka mengalami kesulitan untuk menentukan musim yang sangat mereka perlukan. Maka, bangsa ini membagi tahun dalam jenis Syamsiyah dan Qamariyyah, namun untuk agar hitungan keduanya sama maka setiap tahun kabisat (tahun panjang) dari Qamariyyah terdiri dari 13 bulan dikenal sebagai bulan sisipan atau nasi'. Bulan ke 13 itu mereka gunakan untuk melakukan upacara ritual dan pesta pora yang menyesatkan. ${ }^{25}$

${ }^{22}$ http://erwandigunawandly.blogspot.co.id/2014/06/historisitas-hisab-i-kaleidoskop.html diakses pada tanggal 15 November 2017.

${ }^{23}$ Maskufa, Ilmu Falaq., h. 156.

${ }^{24}$ Maskufa, Ilmu Falaq., h. 156.

${ }^{25}$ Maskufa, Ilmu Falaq., h. 157. 
Hanya saja, mereka belum memiliki acuan hitungan terkait angka tahun. Masyarakat Arab bisa mengetahui tanggal dan bulan, tapi tidak dengan tahunnya. Biasanya, acuan tahun yang mereka gunakan adalah peristiwa terbesar yang terjadi ketika itu. Dalam referensi sejarah biasanya ditemukan istilah tahun Gajah, karena pada saat itu terjadi peristiwa besar yakni serangan pasukan gajah dari Yaman oleh raja Abrahah. Tahun Fijar, karena ketika itu terjadi perang Fijar. Tahun renovasi Ka'bah, karena ketika itu Ka'bah rusak akibat banjir dan dibangun ulang. Bangsa Arab sepakat bahwa tanggal satu dimulai dengan kemunculan hilal dan memberi nama bulan-bulan seperti saat ini. Mereka juga mengenal bulan-bulan suci yang diharamkan untuk berperang (yakni bulan Dzulqa'dah, Dzulhijjah, Muharram dan Rajab). Namun karena alasan kepentingan dan keuntungan kelompok dan individual maka kesucian bulan digeser pada bulan selanjutnya. ${ }^{26}$

Berdasarkan catatan sejarah, shalat baru diwajibkan pada 16 bulan sebelum nabi hijrah ke Madinah pada peristiwa Isra' Mi' raj. ${ }^{27}$ Sedangkan puasa Ramadhan sebagai ibadah wajib bagi umat Islam diwajibkan pada tahun kedua Hijriah. Adapun aturan dan syariah lain yang terikat waktu sebagaimana hukum 'iddah juga baru diturunkan di periode Madinah. Ini menegaskan bahwa ibadah dan kewajiban keagamaan yang menuntut penguasaan dan kemahiran "membaca" langit baru-baru hadir sekitar di paruh akhir masa kenabian.

Saat itu, bangsa Arabkhususnya umat Islam disatu sisi memang terkenal dengan kelebihan kecerdasan dalam menghafal, namun di sisi lain tergolong kurang dalam kecakapan membaca, menulis dan berhitung.Ibnu Hajar menyatakan bahwa tidak bisa menulis dan berhitung dalam teks hadis ini dimaknai sebagai secara umum, artinya masih terdapat sahabat yang mengenal baca tulis meski jarang. Selanjutnya hisab disini dimaknai pula sebagai hisab bintang-bintang dan peredarannya. Hingga nabi mengaitkan hukum puasa dan lainnya dengan rukyah untuk menghindarkan umat dari kesulitan dalam melakukan hisab peredaran bintang-bintang tersebut. ${ }^{28}$ Hal yang layak diamati dari teks ini adalah bahwa nabi Muhammad sendiri sudah menyadari bahwa perhitungan akan peredaran bintang dan benda angkasa lainnya adalah bukan hal yang mustahil, meski secara pengetahuan umat Islam belum mencapai fase tersebut.

Pada masa Rasulullah saw, proses melihat (rukyat) hilal sangat sederhana, yaitu cukup dengan menanti matahari terbenam di hari ke 29 kemudian mencari bulan sabit, jika ada dua orang yang melihatnya, sudah bisa dipastikan malam ini adalah tanggal satu (pergantian hari di kalender hijriah terjadi ketika maghrib). jika hilal tidak terlihat, bilangan bulan akan digenapkan menjadi 30 hari sehingga, esok hari masih tanggal 30 bulan yang sama. Tanggal satuakan jatuh besok sore, cara ini sangat sederhana dan sangat cocok dengan keadaan umat islam pada masa itu yang sebagian besar buta huruf (ummiy). ${ }^{29}$

Dari sini dapat dikatakan, bahwa secara sederhana keilmuan Falak juga dipraktekkan nabi dan sahabatnya. Hanya saja di masa ini, penentuan awal waktu shalat atau awal bulan yang berimplikasi langsung pada banyak ibadah

\footnotetext{
${ }^{26}$ Kementerian Agama Republik Indonesia. Al-Quran dan Tafsirnya vol IV. 2012. h.111-112.

${ }^{27}$ Abdul Hasan Ali al-Nadwi, Sejarah Lengkap Nabi Muhammad saw. Terj. Muhammad Habi Hamdi. Yogyakarta: Darul Manar. 2012. h.159.

${ }_{28}^{28}$ Abdul Hasan Ali al-Nadwi, Sejarah Lengkap Nabi Muhammad saw. h.127.

${ }^{29}$ Sakirman, menelisik Metodelogi Hisab Rukyah di Indonesia, Hunafa: Jurnal Studia Islamika, Vol.8, No.2, Desember 2011, h.346.
} 
hanya melalui observasi (rukyah) dan melihat langit. Tidak dengan pengamatan mendalam dan hitungan matematis. Jika pun ada sahabat yang mampu membaca, menulis hingga melakukan perhitungan maka itu sangat terbatas dan tidak dikuasai secara umum.

b. Hisab Rukyah pada Masa Sahabat

Mengacu pada definisi Ibn Hajar $^{30}$, sahabat dimaknai sebagai orang yang berinteraksi dengan nabi Muhammad saw, beriman pada Islam dan meninggal dalam kondisi Islam. Hingga dari definisi ini dapat dipetakan bahwa sahabat nabi bukan hanya nama-nama besar yang tercatat dalam sejarah, namun banyak pula yang tergolong sahabat kecil karena interaksi yang sesaat dengan nabi. Sebagian dari mereka masih hidup dalam kurun waktu lama dan tersebar di beberapa wilayah sebagai konsekuensi logis dari semakin luasnya wilayah Islam. Tercatat bahwa sahabat yang terakhir meninggal adalah Abu Thufail 'Amir bin Wathilah al-Laithi pada tahun $100 \mathrm{H}$ di Makkah.

Hal lain yang perlu dicatat adalah bahwa di tahun 2 Hijriyah pula terjadi perang Badar yang menuai hasil kemenangan bagi umat Islam. Dari sekian tawanan perang, tebusan yang diinginkan umat Islam tidak selalu berupa harta benda, namun juga dengan mengajarkan membaca dan menulis pada anak-anak kaum muslim, diantara sahabat yang belajar dengan cara ini adalah Zaid bin Tsabit. ${ }^{31}$ Dan dikemudian hari, Zaid dikenal karena kontribusinya yang besar dalam pembukuan al-Quran. Ini mengindikasikan bahwa secara bertahap pada dasarnya nabi membuka jalan bagi umat Islam untuk mampu menguasai baca tulis sebagai step awal untuk membuka cakrawala pengetahuan dan peradaban umat Islam.

Selain itu, Ali bin Abi Thalib pun dikenal sebagai sahabat yang cerdas dan menguasai beragam keilmuan. Diantara bukti keahlian matematika Ali adalah kisah saat seorang pendeta yang melakukan test case terhadap Ali dengan menanyakan bilangan yang habis dibagi angka satu hingga sepuluh. Ali tidak lantas memberi jawaban, namun meminta pendeta Yahudi tersebut untuk mengkalikan jumlah hari dalam sebulan dengan jumlah bulan dalam setahun serta jumlah hari dalam seminggu. Dari $30 \times 12 \times 7$ diperoleh angka 2.520 yang merupakan bilangan terkecil yang bisa dibagi angka 1 hingga $10 .^{32}$

Hal yang menarik bukan pada ketepatan jawaban Ali, namun pada kecerdasannya dalam mengilustrasikan jawaban dengan cara yang relatif mudah dipahami dan menghubungkannya dengan konsep ruang dan waktu yang digunakan manusia sehari-hari. Jawaban ini memicu analisis bahwa Ali memaknai bahwa rumusan matematika merupakan dunia yang tak terpisahkan dari dunia nyata, Bahwa bisa jadi menurut Ali angka-angka itu berkorelasi dengan fenomena kosmologis atau justru fenomena alam raya memiliki rumusan matematis yang serasi. ${ }^{33}$

Namun meski demikian, hal yang perlu dicermati dari masa ini adalah adanya penetapan tahun Hijriah di masa pemerintahan Khalifah Umar bin alKhattab pada tahun $17 \mathrm{H}$ sebagai tonggak sejarah baru umat Islam dalam dunia ilmu hisab dan astronomi. Dalam penuturan sebelumnya dikatakan bahwa umat Islam memang telah mengenal sistem kalender sederhana, yakni dengan mengetahui tanggal dan bulan tanpa tahun. Dalam kurun waktu tertentu hal ini

\footnotetext{
${ }^{30}$ Ibn Hajar Al-Asqalani, Al-Isabah fi Tamyiz al-Sahabah vol I. Mesir: Dar al-Kutub. 1853. h.4.

${ }^{31}$ Abdul Hasan Ali al-Nadwi, Sejarah Lengkap Nabi Muhammad saw. h.263.

${ }^{32}$ Husein Heriyanto, Menggali Nalar Saintifik Peradaban Islam. Bandung: Mizan. 2011. h.106.

${ }^{33}$ Husein Heriyanto, Menggali Nalar Saintifik. h.107.
} 
tentu menjadi penyebab kerancuan sebagaimana kasus surat Abu Musa alAsh'ari yang merupakan gubernur Basrah pada Umar, Abu Musa menyatakan ${ }^{34}$ :

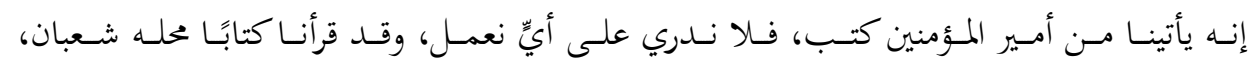

$$
\text { فلا ندري أهو الذي نحن فيه أم الماضي }
$$

"Telah datang kepada kami beberapa surat dari amirul mukminin, sementara kami tidak tahu kapan kami harus menindaklanjutinya. Kami telah mempelajari satu surat yang ditulis pada bulan Sya'ban. Kami tidak tahu, surat itu Sya'ban tahun ini ataukah tahun kemarin."

Dari sini, Khalifah 'Umar akhirnya mengumpulkan sahabat dan bermusyawarah tentang urgennya keberadaan kalender. Terdapat empat usulan tentang awal waktu perhitungan kalender ini, yakni berdasar tahun kelahiran nabi Muhammad saw, tahun diutusnya nabi sebagai Rasul, tahun hijrahnya nabi Muhammad ke Madinah dan tahun wafat beliau. Dari perdebatan dan diskusi panjang pada akhirnya 'Umar menyetujui usul dan argumentasi 'Ali bin Abi Thalib agar berdasar tahun hijrahnya nabi Muhammad.

Adapun terkait penentuan bulan pertama dalam kalender ini diputuskan pada bulan Muharram, berdasar usul Utsman bin 'Affan hal ini didasarkan pada beberapa argument, yakni:

a. Muharam merupakan bulan pertama dalam kalender masyarakatArab dimasa silam.

b. Pada bulan ini, kaum muslimin baru saja menyelesaikan ibadah yang besar yaitu haji ke baitullah.

c. Pertama kali munculnya tekad untuk hijrah adalah terjadi di bulan Muharam. Karena pada bulan sebelumnya, Dzulhijah, beberapa masyarakat Madinah melakukan Baiat Aqabah yang kedua. ${ }^{35}$

Dari sini dapat dipahami bahwa di masa sahabat, perlahan keilmuan hisab mulia tertata dengan baik yang aplikasi positifnya tidak hanya dalam penentuan waktu ibadah, namun juga bermanfaat bagi kepentingan ekonomi, politik, dan pranata sosial dalam skup lebih luas. Di masa ini, umat Islam yang mampu membaca dan menulis juga lebih banyak. Hal ini terindikasikan dari finalnya pembukuan al-Quran dan disalin dalam beberapa mushaf. Serta mulai diidekannya kodifikasi hadis sebagai antisipasi dari bermunculannya hadishadis palsu.

\section{c. Hisab Rukyah pada Masa Tabi'in.}

Jika tabi'in dimaknai sebagai murid langsung dari sahabat dan pernah berinteraksi meski sesaat, maka diduga tabi'in terakhir yang meninggal adalah Khalaf bin Khalifah yang wafat pada tahun $181 \mathrm{H}$. Diabad ini, umat Islam sedang berada dalam masa transisi pemerintahan dari Bani Umayyah menuju Bani Abbasiyyah. Sedikit banyak hal ini juga berpengaruhdalam pengembangan keilmuan. Dimasa dinasti Amawiyyah selama kurun waktu 90 tahun, fokus pemerintahan memang pada membangun dinasti yang kokoh dan ekspansi wilayah Islam.Karena itu, penelitian dan pengembangan keilmuan relatif kurang mendapat apresiasi dari pemerintah.

Meski demikian, bukan berarti masa ini adalah masa stagnansi keilmuan. Karena masa ini adalah masa terpenting dalam sejarah kodifikasi hadis, juga keilmuan tafsir dan asketisme. Sedang dalam sains dan pengetahuan alam,

\footnotetext{
${ }^{34}$ Ibn Hajar Al-Asqalani, Al-Isabah fi Tamyiz. h.268.

${ }^{35}$ Ibn Hajar Al-Asqalani, Al-Isabah fi Tamyiz. h.268.
} 
sejatinya terdapat semisal Khalid bin Yazid bin Mu'awiyah bin Abi Sufyan (w. $85 \mathrm{H} / 704 \mathrm{H}$ ) yang menekuni dunia keilmuan dan sains. Dalam sejarah dikatakan bahwa Khalid mundur dari perebutan kekuasaan sebagai khalifah pasca pemerintahan ayahnya demi menekuni dunia keilmuan.

Perkembangan hisab terbantu oleh hasil penerjemahan karya-karya bangsa Yunani yaitu The Sphere in Movement (al-kurrah al-mutaharrikah) karya Antolycus, Ascentions of The Signs (matali' al buruj) karya Aratus, Introduction to Astronomy (al-madhkhal ila ilmi al-falak) karya Hiparchus, dan Almagesty karya Ptolomeus. ${ }^{36}$ Pada pertengahan abad 4 hijriyah terbukti dengan ditemukannya globe karya batlamus yg disediakan untuk Khalid bin Yazid di perpus Kairo. ${ }^{37}$

Dukungan yang isitimwea yang dipelopori oleh pemerintah dalam pengembangan ilmu astronomi mengalami dampak yang pesat dalam dunia hisab dan rukyah. Dari sinilah mulai dibentuk kajian tidak hanya alamiyah melainkan ilmiah, sehingga waktu itu bermunculan tokoh-tokoh ilmu falak yang berhasil menemukan perhitungan waktu shalat, arah kiblat, rukyatul hilal, perhitungan musim, dan lain-lain.

Di masa ini pula sejatinya penterjemahan buku-buku dari Yunani sebagai aplikasi pengembangan ilmu pengetahuan berawal. Yakni meliputi buku-buku falak dan astronomi, kedokteran hingga kimia dan sebagainya. ${ }^{38}$ Meski telah dimulai sejak masa dinasti Umayyah, perkembangan sains dan keilmuan falak dalam Islam sejatinya benar-benar dimulai saat dipimpin oleh dinasti Abbasiyyah. Penerjemahan besar-besaran dan penelitian serta pengembangan keilmuan Falak benar-benar didukung oleh para khalifah di kurun periode awal bani Abbasiyyah. Dan dari dinasti inilah keilmuan hisab mencapai hasil gemilang dan memberi sumbangsih yang sangat besar bagi perkembangan keilmuan hisab dan astronomi dunia.

Bisa dikatakan hisab yang ada sudah sangat fenomenal karena berhasil mengukur arah kiblat sebagaimana yang ditemukan oleh al-Biruni. Dan rukyah mulai sering diagendakan dengan penemuan hisabnya. ${ }^{39}$

Karna dukungan pemerintah yang besar terhadap ilmu astronomi, maka ilmu ini terus mengalami perkembangan sampai masa khalifah al-makmun. Dan hisab mengalami kemajuan pesat dengan munculnya tokoh-tokoh astronomi Islam masa itu seperti al-Battani ${ }^{40}$ (w.317 H), al-Buzjani (w.387 H), Ibnu Yunus $\left(399\right.$ H), at-Thusi, al-Biruni ${ }^{41}$ w.442 H, dan lain sebagainya. Pada masa ini hisab dalam penentuan waktu shalat, arah kiblat, rukyatul hilal, perhitungan musim, dan lain lain yang telah dituiliskan dalam karya tokoh-tokoh tersebut.

Maka bisa disimpulkan bahwa hisab pada masa ini berkembang pesat daripada sebelumnya. Mereka sudah menggunakannya untuk menentukan waktu ibadah umat Islam (shalat, puasa, arah kiblat, dan juga musim). Adapun

\footnotetext{
${ }^{36}$ Uum Jumsa, Ilmu, ... h. 15 .

${ }^{37}$ Ahmad Musonnif, Ilmu,... h. 15.

${ }^{38}$ Muhammad Bashil al-Tha'i, 'Ilm al-Falak wa al-Taqāwim. Beirut: Dār al-Nafāis. 2007. h.55.

${ }^{39}$ Ahmad Musonnif, Ilmu,... h. 16

${ }^{40}$ Tahun 858-929 M Ibnu Jabr al battani memberi kontribusi besar dalam bidang hisab sepeti perhitungan jalan bintang, garis edar, dan gerhana. Dia juga telah mampu membuktikan kemungkinan

${ }_{41}^{4}$ Ilmu hisab mengalami kemajuan lagi setelah Abdurrahman al-Biruni (w.1048) berhasil menemukan perputaran bumi pada sumbunya dan membuat daftar data lintang dan bujur tempat di permukaan bumi yang sekarang menjadi unsur utama dalam perhitungan waktu-waktu ibadah umat Islam ( arah kiblat, waktu shat, gerhana, awal bulan, dan lain sebagainya.)
} terjadinya gerhana cincin. 
rukyah dalam kaitanya dengan ilmu falak telah dijadikan pondasi dasar untuk menemukan ilmu lain. Disamping untuk pembuktian keakuratan hisab itu sendiri dan juga sebagai metode yang sering dilakukan. Hal ini dengan dibangunnya observatorium untuk mengamati benda-benda langit. ${ }^{42}$

Hingga jika mengacu pada teori circle Ibnu Khaldun, masa awal rintisan ilmu hisab dalam Islam adalah dari periode nabi Muhammad, sahabat hingga tabi'in yang disini banyak bertebaran stimulasi untuk menelaah alam semesta dari ayat al-Quran ataupun hadits nabi Muhammad. Masa keemasannya adalah pada periode awal Abbasiyyah dengan pembangunan Baitul Hikmah yang monumental serta lahirnya banyak ahli sains muslim. Sebagai klimaks adalah pada kurun abad 16 yang merupakan zaman keruntuhan kejayaan Islam sekaligus mulai bersinarnya peradaban Barat.

\section{d. Hisab Rukyat pada masa Pertengahan.}

Dalam khazanah intelektual Islam klasik ilmu hisab sering disebut dengan ilmu falak, miqat, rasd, dan hai'ah. Tak jarang pula disamakan dengan astronomi atau "falak ilmi". Namun dalam perjalanannya ilmu hisab hanya mengkaji persoalan-persoalan ibadah, seperti arah kiblat, waktu salat, awal bulan, dan gerhana. Dr. Yahya Syami dalam bukunya yang berjudul "Ilmu Falak Safhat min at-Turats al-Ilmiy al-Arabiy wa al-Islamiy" memetakan sejarah perkembangan ilmu hisab menjadi dua fase, yaitu fase pra-Islam (Mesir Kuno, Mesopotamia, Cina, India, Perancis, dan Yunani) dan fase Islam.

Fase Islam ditandai dengan proses penerjemahan karya-karya monumental dari bangsa Yunani ke dalam bahasa Arab. Karya-karya bangsa Yunani yang sangat mempengaruhi perkembangan hisab di dunia Islam adalah The Sphere in Movement (Al-Kurrah al-Mutaharrikah) karya Antolycus, Ascentions of The Signs (Matali' al-Buruj) karya Aratus, Introduction to Astronomy (Al-Madhkhal ila Ilmi al-Falak) karya Hipparchus, dan Almagesty karya Ptolomeus.

Pada saat itu, kitab-kitab tersebut tak hanya diterjemahkan tetapi ditindaklanjuti melalui penelitian-penelitian dan akhirnyamenghasilkan teori-teori baru. Dari sini muncul tokoh hisab di kalangan umat Islam yang sangat berpengaruh, yaitu Al-Khawarizmi dengan magnum opusnya Kitab al-Mukhtashar fi Hisab al-Jabr wa al-Muqabalah. Buku ini sangat mempengaruhi pemikiran cendekiawan-cendekiawan Eropa dan kemudian diterjemahkan ke dalam bahasa Latin oleh Robert Chester pada tahun $535 \mathrm{H} /$ $1140 \mathrm{M}$ dengan judul Liber algebras et almucabala, dan pada tahun $1247 \mathrm{H} /$ 1831 M diterjemahkan ke dalam bahasa Inggris oleh Frederic Rosen.

Selain Al-Khwarizmi, tokoh-tokoh yang ikut membangun dan mengembangkan ilmu hisab, diantaranya Abu Ma'syar al-Falakiy (w. 272 H/ 885 M) menulis kitab yang berjudul Haiatul Falak, Abu Raihan al-Biruni (363-440 H/973-1048 M) dengan kitabnya Qanun al-Mas'udi, Nasiruddin at-Tusi (598-673 H/1201-1274 M) dengan karya monumentalnya AtTadzkirah fi 'Ilmi al-Haiah, dan Muhammad Turghay Ulughbek (797-853 H/1394-1449 M) yang menyusun Zij Sulthani. Karya-karya monumental tersebut sebagian besar masih berupa manuskrip dan kini tersimpan di Ma'had al-Makhtutat al-' Arabiy Kairo-Mesir.

\footnotetext{
${ }^{42}$ Ahmad Musonif, Ilmu,... h. 17.
} 
Pada periode pertengahan yang dimulai pada tahun 1200-an hingga 1800an yang merupakan masa setelah terjadinya penyerbuan di Andalusia oleh tentara Kristen, penyerbuan Baghdad dan awal mula Perang Salib (Musyfirah Sunanto, 2004: 177) merupakan masa merangkaknya kembali ilmu pengetahuan di Dunia Islam. Dimana pada masa itu kekuasaan Islam yang berpusat di beberapa daerah mulai melahirkan ilmuwan-ilmuwan besar seperti; Baghdad (1258-1343 M), Iran (1370-1469 M), Mesir (1250-1517 M), Turki (1281-1924 M), Persia (1501-1722 M) dan India (1526-1748 M). ${ }^{43}$

Berkembangnya kembali ilmu pengetahuan di dunia Islam khususnya ilmu falak (Hisab) ditandai dengan lahirnya cendikiawan-cendikiawan muslim walaupun jumlahnya belum banyak. Mereka melakukan inovasi-inovasi luar biasa dalam mengembangannya, seperti Nashiruddin al Thusi dengan inovasinya meletakkan dasar-dasar Hisab Modern dan mendirikan obsevatorium terbesar dan terlengkap di Maragha-Persia. ${ }^{44}$

Pada masa kerajaan Mongol, tahun 1477 M pemerintahan berada di tangan Ulugh Beig (w. 1449 M). Beliau merupakan raja yang alim dan sarjana ilmu pasti serta ahli Hisab (Yatim, 2010: 123) dan berhasil mendirikan obsevatorium termegah di Samarkhand dengan radius kubah mencapai 130 kaki. Obsevatorium ini sangat bermanfaat bagi para ahli Hisab Arab pada masa itu. Mereka mampu mengukur kemiringan poros bumi dan memperbaiki pergerakan rotasi bumi selama hamper 26.000 tahun. Selain itu, mereka juga dapat menemukan lingkar bumi serta pergerakan / detik matahari tiap tahunnya.

Namun akibat serangan bangsa Mongol yang mengakibatkan traumayang masih melekat dalam benak mereka berdampak pada penurunan kreatifitas dalam mengembangkan khasanah keilmuan yang mereka miliki. Mereka melarikan diri dan menyebar ke berbagai wilayah. Hal ini berimbas terhadap pengerucutan substansi ilmu pengetahuan yang cakupan pembahasannya menjadi kerdil. (Musyfirah Sunanto, 2004: 193) Keilmuan mereka juga menyempit pada keilmuan keagamaan saja sehingga banyak yang terjerumus ke hal-hal mistik dan khurafat. Khususnya ilmu falak (Hisab) ruang lingkupnya hanya membahas yang berkaitan dengan keagamaan saja, seperti penentuan arah kiblat, waktu salat, awal bulan. Sedangkan masalah perbintangan dikhususkan untuk peramalan saja.

Masa keemasan kembali di tangan kaum muslim pada saat Izzudin Aibak (w. 1257 M) mendirikan dinasti Mamalik (1249 - 1517 M) di Mesir. Beliau berhasil mempertahankan Mesir dari penyerbuan tentara Mongol. Sejak saat itu Mesir menjadi daerah tumpuan harapan para cendikiawan muslim dalam mengembangkan keilmuan mereka. Namun, perkembangan ilmu pengetahuan itu menjadi tidak berarti, hal ini dikarenakan beberapa factor, yaitu; sarana untuk pengembangan ilmu pengetahuan dan pemikiran baik yang diterjemahkan dari bahasa Yunani, Persia, India, dan Syiria hancur akibat serangan tentara Mongol; kekuasaan Islam pada tiga kerajaan besar dipegang oleh bangsa Turki dan Mughal yang lebih menyukai perang daripada pengembangan ilmu pengetahuan; tidak berkembangnya metode berpikir rasionalis dan tidak adanya ruang kebebasan berpikir; pusat-pusat kekuasaan Islam tidak berada di wilayah

\footnotetext{
${ }^{43}$ Nurwahidah Fibrianty Alim, Historitas Ilmu Hisab Periode Pertengahan Dan Modern, Makalah Kuliah Hisab Kontemporer pada hari Senin tanggal 21 April 2014 program Pascasarjana IAIN Walisogo Semarang.

${ }^{44}$ Nurwahidah Fibrianty Alim, Historitas Ilmu Hisab,,..2014.
} 
Arab dan tidak pula oleh bangsa Arab; terjadinya stagnasi dalam lapangan ilmu pengetahuan dan tekhnologi dan hanya pengembangan kekuatan militer. ${ }^{45}$

Pada awal abad ke - 20, kajian ilmu falak dibangkitkan kembali dengan munculnya beberapa ahli astronomi Eropa yang melakukan kajian mengenai ilmu falak (Hisab) dengan mengedepankan IPTEK (Ilmu Pengetahuan dan Tekhnologi). Di antara mereka adalah Simon New Comb (1835-1909 M) membuat Almanac Nautika yang merupakan tabel pegangan utama hisab kontemporer di Indonesia hingga saat ini, Walter Bade (1892-1960 M) yang menemukan dua populasi bintang dalam galaksi bima sakti. (Khazin, 2005: 99), Jean Meeus (1928 M), seorang ahli matematika dan astronomi, pengarang buku The Canon Of Solar Eclipse Astronomical Algorim yang menjadi rujukan utama di Indonesia dalam perhitungan benda-benda langit serta Fotheringham yang pada tahun 1910 M dan Maunder pada tahun 1911 M menawarkan kriteria baru untuk rukyat, yaitu hisab (menghitungnya) terlebih dahulu.

Sedangkan pada periode modern ini, hanya sedikit tokoh muslim yang bermunculan dan berdedikasi terhadap ilmu falak (Hisab khusussnya karena khasanah keilmuan mereka mengenai hal tersebut dipersempit hanya pada bidang keagamaan saja seperti penentuan Arah Kiblat, waktu salat, dan penentuan puasa dan hari Raya. ${ }^{46}$

Ilmu hisab kini tidak lagi menjadi ilmu yang tabuh. Hisab dan segala permasalahannya tidak saja merupakan pembicaraan yang menarik, namun pada perkembangannya merupakan suatu ilmu yang senatiasa mendapat perhatian. Ini terbukti dengan berbagai macam pertemuan yang diselenggerakan berkaitan dengan ilmu hisab, tidak hanya pada tingkat nasional tetapi juga pada tingkat internasional. Terakhir yang dilaksanakan pada penghujung tahun 2008 adalah "

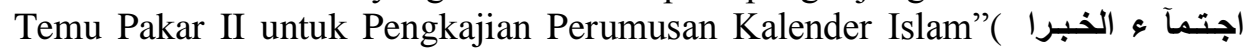
The second Experts' Meeting for the Study of Establishment of the Islamic Calender), yang diselenggarakan di Rabat Maroko tanggal 15 - 16 Syawal 1429 H / 15 - 16 Oktober 2008 atas kerjasama ISESCO, Asosiasi Astronomi Maroko dan Organisasi Dakwah Islam Internasional Libia. ${ }^{47}$

\section{e. Hisab Rukyat di Indonesia.}

Dalam lintasan sejarah, selama pertengahan pertama abad ke-20, peringkat kajian Islam yang paling tinggi hanya dapat dicapai di Mekah, yang kemudian diganti di Kairo. ${ }^{48}$ Sehingga kajian Islam termasuk kajian hisab rukyat yang tidak dapat lepas dari adanya jaringan ulama yang dilakukan oleh ulama-ulama hisab rukyat Indonesia, seperti Muhammad Manshur al-Batawi, yang dalam lacakan sejarah kitab monumentalnya Sullamun Nayyirain adalah hasil dari rihlah ilmiyyah yang beliau lakukan selama di Jazirah Arab.Sehingga diakui atau tidak, pemikiran hisab rukyat di Jazirah Arab seperti di Mesir, sangat berpengaruh dalam pemikiran hisab rukyat di Indonesia. Begitu juga beberapa kitab hisab rukyat yang berkembang di Indonesia menurut

\footnotetext{
${ }^{45}$ Nurwahidah Fibrianty Alim, Historitas Ilmu Hisab,,.. 2014.

${ }^{46}$ Nurwahidah Fibrianty Alim, Historitas Ilmu Hisab,,.,2014.

${ }^{47}$ Nurwahidah Fibrianty Alim, Historitas Ilmu Hisab,,..2014.

${ }^{48}$ Mark R.Woodward, Jalan Baru Islam Memetakan Paradigma Mutakhir Islam Indonesia, terj. Ihsan Ali Fauzi, Bandung: Mizan, cet. Ke-1, 1998.
} 


\section{ELFALAKY: Jurnal Ilmu Falak}

Taufik. ${ }^{49}$ Sehingga dalam perjalanan sejarah hisab rukyat di Indonesia tidak bisa lepas dari sejarah Islam di Indonesia yang memang merupakan hasil dari jaringan ulama. ${ }^{50}$

Sejarah mencatat bahwa sebelum kedatangan agama Islam, di Indonesia telah tumbuh perhitungan tahun yang ditempuh menurut kalender Jawa Hindu atau tahun Soko yang dimulai pada hari Sabtu, 14 Maret 78 M yakni tahun penobatan Prabu Syaliwohono (Aji Soko). Dan kalender inilah yang digunakan umat Budha di Bali guna mengatur kehidupan masyarakat dan agama. Namun sejak tahun $1.043 \mathrm{H} / 1633 \mathrm{M}$ yang ketepatan 1.555 tahun Soko, tahun Soko diasimilasikan dengan Hijriyah, kalau pada mulanya tahun Soko berdasarkan peredaran Matahari, oleh Sultan Agung diubah menjadi tahun Hijriyah yakni berdasarkan peredaran bulan, sedangkan tahunnya tetap meneruskan tahun Saka tersebut. $^{51}$

Di Indonesia ilmu Hisab juga berkembang pesat. Dalam Ensiklopedi Islam Indonesia dinyatakan bahwa ulama yang pertama terkenal sebagai bapak hisab Indonesia adalah Syekh Taher Jalaluddin al-Azhari. Namun, menurut penelusuran penulis sebenarnya selain Syekh Taher Jalaluddin pada masa itu juga ada tokoh-tokoh hisab yang sangat berpengaruh, seperti Syekh Ahmad Khatib Minangkabau, Syekh Muhammad Arsyad al-Banjari, Ahmad Rifa'i, dan K.H. Sholeh Darat.

Selanjutnya perkembangan ilmu hisab di Indonesia dipelopori oleh K.H. Ahmad Dahlan dan Jamil Djambek. Kemudian diteruskan oleh anaknya Siraj Dahlan dan Saadoe'ddin Djambek (1330-1398 H/ 1911-1977 M). Diantara murid Saado'eddin yang menjadi tokoh hisab adalah $H$. Abdur Rachim. $^{52}$

Setelah adanya penjajahan Belanda di Indonesia terjadi pergeseran penggunaan kalender resmi pemerintahan, semula kalender Hijriyah dirubah menjadi kalender masehi (miladiyyah). Meskipun demikian, umat Islam tetap menggunakan kalender Hijriyah, terutama daerah-daerah kerajaan Islam. Tindakan ini tidak dilarang oleh pemerintah kolonial bahkan penetapannya diserahkan kepada penguasa kerajaan-kerajaan Islam yang masih ada, terutama penetapan terhadap hari-hari yang berkaitan dengan persoalan ibadah, seperti 1 Ramadhan, 1 Syawal, dan 10 Dzulhijjah. ${ }^{53}$

Disamping adanya upaya membumikan kalender Hijriyah dengan adanya asimilasi, prosesi tersebut nampak dengan adanya perkembangan yang pesat, sejak abad pertengahan yang didasarkan pada sistem serta tabel matahari dan bulan yang disusun oleh astronom Sultan Ulugh Beik Asmarakandi. Ilmu falak ini berkembang dan tumbuh subur terutama di pondok pesantren di Jawa dan Sumatera. Kitab-kitab ilmu hisab yang dikembangkan para ahli hisab di

\footnotetext{
${ }^{49}$ Taufik adalah pakar ilmu falak Indonesia, pernah menjabat sebagai Direktur Badan Hisab rukyat Indonesia pada masa pemerintahan Gus Dur menjabat sebagai wakil ketua Mahkamah Agung. (Dalam buku Ahmad Izzuddin, Fiqh Hisab Rukyah, Menyatukan NU. h. 75).

${ }^{50}$ Ahmad Izzuddin, Fiqh Hisab Rukyah, Menyatukan NU dan Muhammadiyah dalam Penetapan Awal Ramadhan, Idul Fitri, dan Idul Adha, Jakarta: Erlangga, 2007. h. 55.

${ }^{51}$ Penggagasan dan pencetus pertama, penanggalan ini gabungan tersebut yang selanjutnya dikenal dengan kalender Jawa (Islam) ialah Sri Sultan Muhammad Sultan Agung Prabu Hanyakrakusuma (raja kerajaan Mataram II 1613 - 1645), (Muhammad Wardan, 1957 : 12, Marsito, 1960 : 75 ).

52 http://museumastronomi.com/sejarah-dan-dinamika-pemikiran-hisab-muhammadiyah/di akses tanggal 5 November 2017.

${ }^{53}$ Rohadi Abdul Fatah, Almanak Hisab rukyat, Jakarta: Badan Hisab rukyat Depag RI, 2010, h. $111-113$
} 


\section{ELFALAKY: Jurnal Ilmu Falak} Vol. 3. Nomor 2. Tahun $2019 \mathrm{M} / 1441 \mathrm{H}$

Indonesia biasanya mabda' (epoch) dan markaznya disesuaikan dengan tempat tinggal pengarangnya. Seperti Nawawi Mahammad Yunus al-Kadiri dengan karyanya Risalatul Qamarain dengan markaz Kediri, kitab Irsadul Murid karya Ahmad Ghazali Madura. ${ }^{54}$

Walaupun ada juga yang tetap berpegang pada kitab asal (kitab induk) seperti al-Mathla'ul Said fi Hisabil Kawakib ala Rasydil Jadid karya Syeh Husain Zaid al-Misra dengan markaz Mesir. ${ }^{55}$ Dan sampai sekarang, khazanah (kitab-kitab) ilmu falak di Indonesia dapat dikatakan relatif banyak, apalagi banyak pakar falak sekarang yang menerbitkan (menyusun) kitab falak dengan cara mencangkok kitab-kitab yang sudah lama ada di masyarakat di samping adanya kecanggihan teknologi yang dikembangkan oleh para pakar Astronomi dalam mengolah data-data kontemporer yang berkaitan dengan hisab rukyat.

Pada dasarnya persoalan hisab rukyat tidak hanya persoalan penentuan awal bulan Kamariyah (dalam hal ini penentuan awal Ramadhan, Syawal dan Dzulhijjah). ${ }^{56}$ Muara perbedaan pemikiran hisab rukyat di Indonesia pada dasarnya tidak berbeda dengan muara perbedaan pemikiran para fuqaha (terdahulu) yakni pada perbedaan pemahaman hadis-hadis hisab rukyat. ${ }^{57}$ Hanya saja dalam wacana pemikiran hisab rukyat di Indonesia, ragam pemikirannya lebih majemuk dibanding ragam pemikiran dalam wacana hisab rukyat pada kalangan para fuqaha (terdahulu). Hal ini karena sentuhan Islam sebagai great tradition dan budaya lokal atau little tradition yang sering menimbulkan corak budaya tersendiri yang di luar dugaan. Dalam konteks ini disebut sebagai paham keislaman yang bersifat lokal, seperti Islam Jawa - atau dalam bahasa Geertz disebut Religion of Java. ${ }^{58}$

Di antara pemikiran-pemikiran hisab rukyat yang ada di Indonesia yaitu :

1. Pemikiran Hisab Rukyat Lokal.

Di antara pemikiran hisab rukyat lokal adalah pemikiran Aboge atau Asapon yakni cara penentuan awal Ramadhan, Syawal dan Dzulhijjah bersandarkan perhitungan tahun Jawa lama (khuruf Aboge atau khuruf Asapon) dan rukyatul hilal (observasi dengan mata telanjang saat tenggelamnya matahari). ${ }^{59}$

Dalam pemikiran Aboge ada beberapa prinsip utama, yakni: Pertama, prinsip penentuan tanggal selain berdasarkan kalender HinduMuslim-Jawa, adalah dina niku tukule enjing lan ditanggal dalu (hari itu lahirnya pagi dan diberi tanggal malam harinya).Kedua, bahwa jumlah hari dari bulan puasa menurut cara perhitungan Aboge selalu genap 30 hari, tidak

\footnotetext{
${ }^{54}$ Sriyatin Sadik, Perkembangan Hisab rukyat dan penetapan awal bulan Qomariah, dalam Menuju Kesatuan Hari raya, Surabaya: Bina Ilmu, 1995, h. 64-66.

${ }^{55}$ Al-Khulasatul Wafiyah karya Zubaer Umar al-Jailany dengan markaz Mesir, al-Hamihijul Hamidiyah karya Abdul Hamid Mursy dengan markaz Mesir, dan masih banyak lagi, Ibid., h. 67-68.

${ }^{56} \mathrm{Di}$ antara kedua belas bulan hijriyah yang paling mendapat perhatian umat Islam adalah bulan Ramadan, Syawal dan Dulhijjah, sebab di dalamnya terdapat kewajiban berpuasa dan haji atas umat Islam. Lihat Q.S. Al-Baqarah : 185 dan 197. Penetapan awal bulan hijriyah selain ketiga bulan tersebut dapat dipakai hisab karena dalam $\mathrm{h}$ ini tidak diperlukan isbat al-Qadli. Penetapan bulan ini semata-mata untuk perhitungan waktu tidak benar-benar untuk kepentingan ibadah. Baca Imam Abu Al-Hayyan, Al-Bahr alMuhith, Kairo : Beirut, jilid II, h. 62.

${ }^{57}$ Banyak hadis-hadis hisab rukyat yang secara redaksional berbeda-beda tetapi secara esensial tidak jauh berbeda, di antaranya redaksinya: Shumu lirukyatihi wa afthiru lirukyatihi fa in ghumma faqduru lahu Baca Abu Husen Muslim bin al-Hajjaj, Shahih Muslim, Kairo, t.th, h. 481.

${ }^{58}$ Clifford Geertz, Abangan, Santri, Priyayi dalam Masyarakat Jawa, Jakarta : Pustaka Jaya, 1981.

${ }^{59}$ Andy Ahmad Zaelany, Menentukan Hari Lebaran Ala Islam Jawa Kasus Dusun Golak, Ambahrawa, pada Journal Ulumul Qur'an, no, Vol. VI, tahun 1996, h. 62-70.
} 
pernah 29 hari seperti pada cara perhitungan hari Falak (versi pemerintah). Adapun istilah Aboge dapat dirinci bahwa "a" berasal dari alip, salah satu dari delapan tahun siklus windu bo mengacu pada rebo (hari Rabu); dan ge berasal dari wage, salah satu dari hari pasaran yang lima. Ini berarti bahwa tahun alip selalu dimulai pada hari Rabu Wage, dengan mengetahui ini maka akan dapat menghitung hari jatuh riyaya (hari lebaran) setiap tahun. Cara yang lebih singkat adalah mengambil hari permulaan tahun (1 sura) dan menggunakan rumus waljiro. Wal adalah bulan Syawal, ji berarti tanggal siji (satu), dan ro adalah berarti loro (dua), yaitu hari pasarannya. Ini berarti bahwa hari lebaran jatuh pada tanggal 1 Syawal dihitung dengan menghitung satu dari hari mingguan dan dua dari hari pasaran pada permulaan tahun. Misalnya, kalau permulaan tahun itu Ehe, dan tanggal 1 Sura pada hari Ngahad Pon, maka hari lebaran akan jatuh pada hari Ngahad Wage. ${ }^{60}$ Ketiga, penentuan awal bulan puasa dan awal bulan Syawal digunakan istilah pletek yang berarti terbukti atau semua masyarakat telah melihat bulan dengan mata telanjang, sebagaimana dasar dari hadishadis hisab rukyat. ${ }^{61}$

Namun jika ditilik dari perjalanan historis pemikiran hisab rukyatlokal ala Islam Jawa, ternyata berasal dari pemikiran hisab rukyat(kalender) Saka ${ }^{62}$ yang diperbaharui oleh Sultan AgungHanyokrokusumo ${ }^{63}$ yakni disesuaikan dengan perhitungan lunar (Qamariyah) tidak lagi menggunakan sistem perhitungan solar(Syamsiyah).

Peralihan tersebut terjadi pada tanggal 1 Sura tahun Alip 1.555

(Tahun Jawa) yang bertepatan dengan tanggal 8 Juli 1633 M yakni hari Jum'at Legi. ${ }^{64}$ Dari tahun $1633 \mathrm{M}$ sampai sekarang, kalender ini sudah tiga kali mengalami penyesuaian kalender, sehingga sampai sekarang sudah mengalami perubahan empat kali dasar permulaan awal tahun yakni mulai dengan pemikiran hisab rukyat Ajumgi (tahun alip mulai pada hari Jum'at Legi), kemudian Akawon (tahun alip mulia pada hari Kamis Kliwon), kemudian Aboge (tahun alip mulai pada hari Rebu Wage), kemudian Asapon (tahun alip mulai pada hari Selasa Pon). ${ }^{65}$

Metode yang terakhir inilah (pemikiran Asapon) yang sampai sekarang dipegangi mayoritas umat Islam Jawa (Kejawen) terutama di kalangan lingkungan kraton Yogyakarta. ${ }^{66}$

\footnotetext{
${ }^{60}$ Clifford Geertz, Op. Cit., h. 510.

${ }^{61}$ Andy Ahmad Zaelany, Op. Cit., h. 67.

${ }^{62}$ Saka secara bahasa (Jawa) berarti perbuatan, berasal dari kata Sansekerta Syaka yang berarti
} bangsa seyth. Sedangkan menurut kamus Jawa Kuno (Kawi) : Soko atau sakabda yang berarti tahun saka (mulai tahun $76 \mathrm{M}$ oleh Sahwaha) yakni perhitungan menurut perjalanan matahari, atau dalam arti tahun Hindu yang dimulai bertahtanya Adji Saka. (C. C. Berg, Penulisan Sejarah Jawa, Terj. S. Gunawan, Jakarta : Bratara Karya Aksara, 1985, h. 93), L. Wardiwarsito, Kamus Jawa Kuno (Kawi) - Indonesia, Jakarta : Nusa Indah, 1978, h. 330, dan dalam buku S. Prawiro Atmojoyo, Bausastra Jawa - Indonesia, jilid II, Jakarta : Masagung, 1980, h. $158-159$.

${ }^{63}$ Sri Sultan Muhammad Sultan Agung Prabu Hanyokrokusumo adalah raja pada kerajaan Mataram II pada tahun 1613 - 1645 M, (Ahmad Izzuddin, Fiqh Hisab Rukyah, Menyatukan NU. H. 75).

${ }^{64}$ Kartono Kamajaya Partokusumo, Kebudayaan Jawa Perpaduannya Dengan Islam, Yogyakarta : Aditya Media, 1995, h. 200.

${ }^{65}$ Slamet Hambali, Pengantar Ilmu Falak, Menyimak Proses Pembentukan Alam Semesta. Banyuwangi : Bismillah Publisher. 2012. H. 289.

${ }^{66}$ Tjokorda rai Sudharta, I Gusti Oka Hermawan, W. Winda Winaban, Kalender 301 Tahun, Jakarta : Balai Pustaka, 1984, h.22. 
Namun pemikiran Asapon yang notabene pemikiran hisab rukyat tradisional yang terbaru juga hidup di masyarakat. Malahan menurut perhitungan kalender Jawa, pemikiran Aboge sudah harus diganti dengan pemikiran Asapon, ${ }^{67}$ tapi dalam dataran realitas ternyata pemikiran Aboge masih berlaku juga di kalangan umat Islam Jawa sebagaimana tersebut di atas.

2. Pemikiran Rukyat.

Dalam wacana hisab rukyat di Indonesia, pemikiran rukyat ini selalu diidentikkan dengan pemikiran hisab rukyat Nahdlatul Ulama. Namun pengidentikkan ini kiranya tidak dapat diterima seratus persen kebenarannya. Karena pada dasarnya dalam pemikiran rukyat terdapat beberapa pemikiranpemikiran kecil yang mempunyai perbedaan-perbedaan yang prinsipil, dan Nahdlatul Ulama sendiri termasuk salah satu dari pemikiran kecil tersebut.

Pemikiran-pemikiran kecil tersebut muncul karena adanya perbedaan pemahaman term rukyat. Di antaranya dalam hal : pemahaman mathla'. ${ }^{68}$ Ada yang berpendapat bahwa hasil rukyat di suatu tempat berlaku untuk seluruh dunia. Dengan argumentasi bahwa hadis-hadis hisab rukyat khithabnya ditujukan pada seluruh umat Islam di dunia, tidak dibedakan oleh perbedaan geografis dan batas-batas daerah kekuasaan.

Pemikiran inilah yang terkenal dengan rukyat Internasional yang dipegang oleh Komisi Penyatuan Kalender Hijriyyah Internasional, di mana dalam konteks ke-Indonesia-an adalah kelompok Hizbut Tahrir. ${ }^{69}$

Mereka memandang bahwa yang menjadi dasar penetapan adalah sebab syar'i untuk berpuasa dan berhari raya yaitu rukyatul hilal bil 'ain (melihat bulan sabit dengan mata). Sesuai dengan hadits berpuasalah kamu karena melihat hilal dan berbukalah kamu karena melihat hilal yang mempunyai pengertian yang jelas (sharihah ad-dalalah). Dan rukyatul hilal yang dimaksud dalam pandangan HTI bukanlah rukyat lokal yang berlaku untuk satu mathla' (madzhab Syafi'i), melainkan rukyah yang berlaku secara global, dalam arti rukyatul hilal di salah satu negeri muslim berlaku untuk kaum Muslimin di negeri-negeri lain di seluruh dunia.

HTI sejalan dengan pentarjihan Imam Syaukani dalam persoalan perbedaan mathla', "yang layak dijadikan pegangan adalah pendapat 'ulama pengikut mazhab Maliki dan golongan Zaidiyah. Imamm al-Mahdi juga memilih pendapat ini, bahkan Imam Qurtubi menceritakan itu pada gurugurunya. Bila ada penduduk suatu negara melihat bulan sabit tanggal satu, maka bagi seluruh penduduk negara yang lain harus mengikutinya (berpuasa pada awal bulan Ramadhan atau berbuka pada permulaan bulan Syawal). Kita tidak usah mempedulikan perkataan Ibnu Abdil Bar yang menyatakan bahwa pendapat tersebut bertentangan dengan ijma' ulama.",0 sehingga HTI tidak dapat menerima faham dari pendapat madzhab Syafi' I yaitu ucapan Ibnu Abbas ra yang mengikuti rukyah Madinah dan tidak mengikuti rukyah Syam, yaitu dengan perkataannya Tidak, demikianlah Rasulullah saw memerintahkan kita menjadi dalil bahwa setiap negeri

\footnotetext{
${ }^{67}$ Slamet Hambali, Loc. Cit. Dan dalam buku H. G. Den Hollander, Beknopt Leerboekje der Cosmografie, Terj. I Made sugita, Jakarta : J. B. Wolters Groningen, 1951, h. 81-83.

${ }^{68}$ Secara definitif kontekstual mathla' berarti batas geografis keberlakuan Rukyat.

${ }^{69}$ Wali al-Fatah, Khilafah Ala Minhajin Nubuwah, Jakarta : Al-Jama'ah, 1990, h. 83.

${ }^{70}$ Ahmad Muhammad Syakir, Menentukan Hari Raya dan Awal Puasa, Surabaya: Pustaka Progressif, Cet. Ke 1, 1993.
} 
mempunyai rukyah sendiri-sendiri, dan rukyah suatu negeri tidak berlaku untuk negeri yang lain, li ikhtilaf mathali (karena ada perbedaan mathla').

Berangkat dari permasalahan pemikiran kecil rukyat di Indonesia tersebut, pada dasarnya merupakan jelmaan dari ragam pemikiran rukyat pada kalangan fuqaha (terdahulu). ${ }^{71}$

3. Pemikiran Hisab.

Sebagaimana dalam pemikiran rukyat, dalam pemikiran hisabpun terdapat ragam pemikiran-pemikiran kecil sebagai dampak dari adanya perbedaan sistem yang dipakai atau yang dipegangi. Di Indonesia sistem hisab yang berkembang pada dasarnya banyak sekali, hanya saja jika ditilik dari dasar pijakannya terbagi dalam dua macam yakni hisab urfi ${ }^{72}$ dan hisab hakiki. $^{73}$

Hisab urfi dalam konteks ke-Indonesia-an sebagaimana dalam pemikiran hisab rukyat lokal ala Islam Jawa yang terekam dalam sistem Aboge dan sistem Asapon. Sedangkan mengenai hisab hakiki dapat dipilah pada pendirian yang mendasarkan pada ijtima' yakni sistem yang berpendapat bahwa hakikat bulan Kamariyah itu dimulai sejak terjadinya ijtima'. Dalam kalangan pemikiran hisab terkenal dengan istilah Ijtima'un Nayyirain Isbatun Bainasy-syahrain, yang sesuai dengan ketentuan astronomi bahwa konjungsi merupakan batas antar dua lunar months.

Oleh karena ijtima itu hanya terjadi sekali dalam sebulan dan tidak ada hubungannya dengan tempat-tempat di muka bumi, maka saat ijtima dialami secara berlainan menurut perhitungan waktu setempat. Ijtima bisa terjadi pada pagi hari pada suatu tempat, yang dalam waktu bersamaan saat itu sedang siang hari atau malam hari di tempat lain. Oleh karena itu dalam prakteknya awal bulan Kamariyah ditetapkan berdasarkan ijtima yang terjadi sebelum matahari terbenam atau sebelum tengah malam, atau sebelum terbit fajar, sesuai dengan perbedaan pandangan tentang kapan dimulainya hari.

Inilah sistem yang dipakai oleh Muhammad Manshur dalam karya monumentalnya Sullamun Nayyirain. Di mana sampai sekarang mengkristal dalam pemikiran kecil yakni pemikiran (kalender) Manshuriyyah, yang banyak dikiblat oleh kalangan hasib-hasib Jawa Timur. ${ }^{74}$

Sistem hisab yang mendasarkan pada posisi hilal, yakni penentuan awal bulan Kamariyah tidak hanya didasarkan pada ijtima' melainkan harus diperhatikan posisi hilal di atas ufuk saat terbenam setelah terjadinya ijtima'. ${ }^{75}$ Dalam sistem ini terbagi menjadi tiga yakni :

\footnotetext{
${ }^{71}$ Syihabuddin Ahmad bin Hajar al-Haitami, Tuhfah al-Muhtaj, jilid III, Kairo : Baerut, t.th., h. 382, dan dalam kitab Abdul Hamid al-Syarwani, Hasyiyah al-Syarwani, jilid III, Kairo : Beirut, t. th., h. 332.

${ }^{72}$ Hisab urfi adalah sistem hisab penentuan awal bulan qamariyah yang didasarkan pada waktu peredaran bulan. Muhammad Nur, Pedoman Perhitungan awal Bulan Qamariah, Jakarta : depag RI, 1983, h. 7. sebenarnya.

${ }^{73}$ Hisab Hakiki adalah sistem hisab yang didasarkan pada peredaran bulan dan bumi yang

${ }^{74}$ Pemikiran kecil Manshuriyyah adalah aliran hisab yang tidak begitu besar dan tidak begitu banyak pengikutnya, bahkan markas Manshuriyyah sendiri terkesan sudah pudar, ini nampak adanya sudah pudarnya Pondok Pesantren yang dulu merupakan pusat hisab Sullamun Nayyirain. Namun sampai sekarang masih sering kali diperhitungkan dalam putusan sidang ithbat yang diselenggarakan oleh pemerintah, ini terbukti masuk dalam berita acara sidang itsbat.

${ }^{75}$ Almanak Hisab rukyat, Kemenag, 2010. Bahwa kelompok yang berpegang pada posisi hilal menetapkan jika pada saat Matahari terbenam posisi hilal sudah berada di atas ufuk, maka sejak matahari terbenam itulah awal bulan baru sudah mulai masuk.
} 
1) Sistem yang berpedoman pada ufuk hakiki yakni ufuk yang berjarak 90 derajat dari titik zenith. Prinsip utama dalam sistem ini adalah sudah masuk bulan baru, bila hasil hisab menyatakan hilal sudah di atas ufuk hakiki (positif) walaupun tidak Imkanurrukyat. Sehingga sistem ini dikenal dengan sistem hisab wujudul hilal sebagaimana prinsip yang dipegang Muhammadiyah secara institusi. ${ }^{76}$

2) Sistem yang berpedoman pada ufuk mar'i yakni ufuk hakiki dengan mempertimbangkan refraksi (bias cahaya) dan tinggi tempat observasi, sebagaimana pendapat yang dipegang pemikiran kecil (kalender) Menara Kudus. $^{77}$

3) Sistem yang berpedoman pada Imkanurrukyat dalam posisi hilal sudah wujud di atas ufuk hakiki atau mar'i, maka awal bulan Kamariyah masih tetap belum dapat ditetapkan, kecuali apabila hilal sudah mencapai posisi yang dinyatakan dapat dilihat.

\section{Kesimpulan}

Berdasarkan uraian singkat ulasan di atas, maka dapat ditarik kesimpulan bahwa hisab rukyah merupakan kajian perhitungan yang telah ada sebelum Islamdatang. Dan kajian tersebut manusia gunakan untuk menandai suatu masa pada saat itu.

Pada periode nabi Muhammad saw., keadaan hisab memang belum berkembang terlebih penanggalan hijriyah yang akhirnya tercetus waktu itu juga hanya sekedar bulan dan tanggal tanpa ada perhitungan tahun. Mereka mengenal penamaan tahun dengan peristiwa-peristiwa penting/bersejarah pada saaat itu seperti tahun gajah dan lain sebagainya. Adapun rukyah yang menjadi kajian saat itu ketika hendak melaksanakan ibadah puasa, shalat masih dengan mengamati benda-benda langit (rukyatul hilal). Tercatat rukyah saat itu yang terekam oleh hadits adalah awal Ramadhan, Syawal, Zulhijjah, dan Muharram.

Pada masa sahabat, kajian hisab mengalami perkembangan yakni di dalam konsep penanggalan yang sudah memakai angka tahun. Adapun dalam kajian rukyahnya masih seperti apa yang dilakukan oleh Nabi saw. sedangkan pada masa tabi'in, Dinasti Umayah menjadi langkah awal dalam perkembangan ilmu falak saat itu yakni dengan mulai dialihbahasakan karya-karya buku Yunani ke dalam bahasa Arab. Dilanjut dengan masa dinasi Abbassiyah yang menjadi gerakan paling banyak dalam pengembangan ilmu pengetahuan, terutama ilmu falak. Hal ini ditandai dengan dibangunnya observatorium, penerjemahan buku-buku Yunani, India, dan lain sebagainya.

Pada masa era modern, dimulai dengan munculnya ilmu teknologi seperti teleskop sehingga era selanjutnya rukyah mengalami kemajuan pesat dengan menghasilkan datadata astronomis yang akhirnya diadopsi oleh tokoh-tokoh Islam selanjutnya dan hingga sampailah ke Indonesia.

\footnotetext{
${ }^{76}$ Himpunan Putusan Majlis Tarjih Muhamadiyyah, cet. III, t.th., h. 291-292.

${ }^{77}$ Slamet Hambali, Al-Ahkam, no.10, Fakultas Syari'ah IAIN Walisongo Semarang, 1993.
} 


\section{DAFTAR BACAAN}

Ahmad Muhammad Syakir, Menentukan Hari Raya dan Awal Puasa, Surabaya: Pustaka Progressif, Cet. Ke 1, 1993.

Al-Fatah, Wali, Khilafah Ala Minhajin Nubuwah, Jakarta : Al-Jama'ah, 1990.

Almanak Hisab rukyat, Kemenag, 2010.

Atmojoyo, S. Prawiro Bausastra Jawa - Indonesia, jilid II, Jakarta : Masagung, 1980.

Azhari, Susiknan, Ensiklopedi Hisab Rukyat, Yogyakarta : Pustaka Pelajar, Cet. Ke II (Edisi Revisi) 2008.

Azhari, Susiknan, Ilmu Falak Teori dan Praktik, Jogyakarta, Lazuardi, Cet. ke 1, 2001.

Azhari, Susiknan, Hisab dan Rukyat,Wacana untuk Membangun Kebersamaan di Tengah Perbedaan, Yogyakarta : Pustaka Pelajar, Cet. Ke I. 2007

Azhari, Susiknan, Revitalisasi Studi Hisab Rukyah di Indonesia, dalam al-Jami'ah Pasca IAIN Yogyakarta, no. 65/VI/2000.

C. Berg, Penulisan Sejarah Jawa, Terj. S. Gunawan, Jakarta : Bratara Karya Aksara, 1985

Clifford Geertz, Abangan, Santri, Priyayi dalam Masyarakat Jawa, Jakarta : Pustaka Jaya, 1981.

Depag, Himpunan Keputusan Menteri Agama tentang Penetapan Tanggal 1 Ramadan dan 1 Syawal tahun $1381-1418$ h / 1962-1997 M.

Diponingrat, K. Wardan, Hisab Hakiki, Jogyakarta: Toko Pandu, 1955.

Direktorat Jendral Bimas Islam dan Penyelengara Haji Direktorat Pembinaan Peradian Agama, Selayang Pandang Hisab Rukyah, Jakarta: 2004.

Fatah, Rohadi Abdul, Almanak Hisab rukyat, Jakarta: Badan Hisab rukyat Depag RI, 2010.

Hambali, Slamet, Pengantar Ilmu Falak, Menyimak Proses Pembentukan Alam Semesta, Yogyakarta : Bismillah Publisher. Cet. Ke I. 2012.

Hambali, Slamet, Almanak Sepanjang Masa, Semarang : Fakultas Syari'ah IAIN Walisongo, 1978.

Hamid, Abu Hamdan Abdul jalil bin Abdul, Fathu rauful manan, Kudus, Menara Kudus, t.th.

Hollander, H. G Den, Beknopt Leerboekje der Cosmografie, terj. I Made Sugita, Jakarta, J.B. Wolters Groningen, 1951.

Izzuddin, Ahmad, Ilmu Falak Praktis (Metode Hisab Rukyah Praktis dan Permasalahannya, Semarang: Komala Grafika, 2006. , Ilmu Falak, Jakarta: CV. Tarity Samudra Berlian, 2006.

, Fiqh Hisab Rukyah, Menyatukan NU dan Muhammadiyah dalam Penetapan Awal Ramadhan, Idul Fitri, dan Idul Adha, Jakarta: Erlangga, 2007.

, Menentukan Arah Kiblat Praktis, Yogyakarta: Logung, 2010.

Kartono Kamajaya Partokusumo, Kebudayaan Jawa Perpaduannya dengan Islam, Yogyakarta : Aditya Media, 1995.

Wardiwarsito, Kamus Jawa Kuno (Kawi) - Indonesia, Jakarta : Nusa Indah, 1978.

Ma'shum, Badiatul Mitsal, Jombang : t.th.

Manshur, KH Mas, Sullamun Nayyirain, Jakarta: Al-Manshuriyah, 1988.

Mark R.Woodward, Jalan Baru Islam Memetakan Paradigma Mutakhir Islam Indonesia, terj. Ihsan Ali Fauzi, Bandung: Mizan, cet. Ke-1, 1998.

Marsito, Enciclopedia Britanicca, London, Chicago, 1768.

Maskufa, Ilmu Falaq, Jakarta : Gaung Persada, 2009.

MUI Daerah Istimewa Yogyakarta, Kalender Islam Sultan Agung adalah Kalender Nasional, Yogyakarta : Offset, 1987. 


\section{ELFALAKY: Jurnal Ilmu Falak}

Vol. 3. Nomor 2. Tahun $2019 \mathrm{M} / 1441 \mathrm{H}$

Nur, Muhammad, Pedoman Perhitungan awal Bulan Kamariyah, Jakarta : depag RI, 1983.

Shidiqi, Naurrozaman, Fiqh Indonesia, Penggagas, dan Gagasannya, Yogyakarta: Pustaka Pelajar, 1995.

Sudharta, Tjokorda rai, I Gusti Oka Hermawan, W. Winda Winaban, Kalender 301 Tahun, Jakarta : Balai Pustaka, 1984. 